\title{
"He Imparted to Me a Sense of Belonging. This is The Greatest Gift a Person Can Receive" The Academic Learning Experience of a Sight Impaired Student
}

\author{
Rivka Hillel Lavian \\ Levinsky College of Education
}

\begin{abstract}
In recent years, a growing number of students with special needs have been enrolled in higher education institutions. This increase has uncovered the need to introduce changes in the system in order to provide suitable support for these students. Understanding the academic, emotional and social difficulties they encounter and understanding their perception can help ease their inclusion and progress. This chapter presents the voice of a visually impaired special education teacher. The autobiography describing her experiences as an academic student, has been holistically analyzed according to the four steps listed in the "Listening Guide" (Brown \& Gilligan 1992). The findings show the voice of disability versus capabilities, with the clear message being the importance of including students with special needs in the academic world and offering them assistance and support both in the application process and throughout their studies.
\end{abstract}

Keywords: Students with disabilities in the academy; Inclusion; narrative research, the "Listening Guide" method.

\section{INTRODUCTION}

In February 2009, In Israel, the Law of Students with Learning disabilities in higher education came into effect. The law seeks to help applicants and students in higher education to exhaust their rights optimally. With the years, a significant need emerged for the integration of students with special needs into higher education institutions so that they can gain an occupation and expand their education. At the same time, public awareness of learning disabilities has increased considerably. A combination of these factors led to a significant rise in the number of students with special needs enrolled in higher education institutions.

The increase in the number of students with special needs in higher education institutions brought about the need for systemic changes so as to give these students the proper support in the course of their academic studies. Understanding the academic, emotional and social difficulties experienced by learning disabled students, and understanding their perceptions might help in the construction of proper, significant support. As the first step in this support, it is important to understand the learning experience of students with special needs. This research will expose the learning experience of a sight impaired student seeking to sound her voice and learn about her needs and her coping in the academic world.

As an academician in the field of special education, I see great significance in encouraging students with special needs so that they can realize their potential and achieving their personal vision. 
In the course of my studies for a teaching certificate in special education, about 30 years ago, there was a hearing impaired student in my class. At the end of the second year of studies, she was informed she could not continue her studies because of her hearing impairment. She did not give in, but continued her studies elsewhere and has been working as a teacher and educator to this day. This episode remained etched in my memory some twenty years later in my capacity of Head of the Special Education Department. This position has afforded me the opportunity to meet students with special needs, among them Avigail, and to accompany them along their far-from-simple path towards receiving their teaching certificate.

This chapter presents the voice of a visually impaired special education teacher. Research has found that the desire to work in special education is closely related to a positive affair with personal or family misfortune (Hillel-Lavain. 2003, 2009; Tangala \& Margaret, 2007). Avigail was accepted and studied during the years I served as Head of the Special Education Department.

\section{Research question:}

The research question that this study examined was: What is the learning experience of a visually impaired student studying in an academic setting?

\section{LITERATURE REVIEW}

In recent years, the number of students with special needs studying in academic institutions has increased, for a number of reasons. Firstly, the Students' Rights Law requires every academic institution to have a support center. Secondly, more students diagnosed, thanks to a growing awareness, demand their rights to accommodations and special provisions in their learning environment and exams (Dahan \& Ziv, 2012).

One of the most prominent difficulties accompanying disability is an impediment in social functioning, which stems, inter alia from low self-image (Dahan \& Ziv, 2012). The difficulty is not simply a matter of being accepted to an academic institution, but also continues after enrollment. These students constantly face complex challenges and experience more tension and anxiety than their fellow students.

These students report high levels of anxiety, low self-image and large gaps between their capabilities and academic achievements (Barton \& Fushrman, 1994). Furthermore, these students reported experiencing more difficulty performing tasks, adjusting to change and coping with criticism (Mellard \& Hazel, 1992).

It was found that beyond the difficulties in academic studies due to the disability, these students had to cope with problems such as: coping with academic demands, adjusting to changes, coping with outside criticism and adjusting to university life.

They experienced frustration while studying and are characterized as being disorganized, which hampers the learning process (Harrison, Areepattamannil \& Freeman, 2012).

Society's lack of knowledge and basic understanding of people with special needs in general, and some types of disability in particular, often places those who are considered "normal" and "others" in challenging situations, which are difficult and painful for both sides. A glass wall has been formed, fed to a great extent, by the stereotype of disability as a disease (Reiter, 2004). 
Interviewees in research that examined the factors behind the success of integrating people with special needs remarked that an important and consequential component in successfully coping with the world at large is receiving support and assistance from various people throughout their lives, who opened up windows of opportunity for them (Mandler \& Naon, 2002).

\section{Motivation in Choosing to Become a Special Education Teacher}

A large body of educational research has discussed the issue of motivation in choosing to become a teacher in mainstream education (Katzin \& Shkedi, 2011; Perry \& Friedman, 2011), whereas this motivation for special education has only been researched in the last decade. A study I conducted (Hillel-Lavian, 2008) was intended to examine this question anew by observing students enrolling in the special education teacher training route. The goal of the study was to examine what motivated the students to become interested in teaching, particularly in choosing special education, via means of personal life narratives. The research population included 20 students.

The narratives yielded a picture of teachers, imbued with motivation, the majority holding a rather personal approach to special education, due to personal and family differences; some were with learning disability, some were new immigrants, some sisters to siblings with special needs, which gave them early in life, successful experience with care, whether in volunteer work, school or in the army. Some of the participants commented on the influence of certain special teachers who were role models for them.

By means of narrative research, teachers' personal stories have acquired a respectable place in research of teaching and teacher training, in recent years. The narrative approach raises two main claims for its use as a tool in teaching research and in teacher education. The first claim is that teachers find expression for many important facets of their work by telling their personal stories, which helps clarify the knowledge they have accrued through their activity and practical understanding. The second claim is that the story serves as a conceptual tool by means of which they can better explain their work (Elbaz-Lubisch, 2002).

Choice of profession is closely associated with the students' life stories, which connect their past, present and future and give meaning their life's continuity beyond the facts, and constitute a significant and central stage in building their identity (Rosenberg, Munk and Keinan, 2008). The use of life stories is a reflection of teachers' practices and serves teacher educators by mirroring the process of teaching, which is actually a journey of reflection and change across the years (Forrest, Keener and Harkins, 2010).

It seems that teachers' and students' life stories can serve as a tool for examining their perceptions and beliefs as well as revealing the motives which led them to choose the teaching profession. Career choice is one of the most important decisions that affect the person's functioning both psychologically and socially (Court, Merav, \& Ornan, 2009). The human desire to work at a personally meaningful job is an existential need. A strong self-identity is necessary to attain self-actualization through a career. A person chooses a profession or career with the aim of fulfilling his/her self-image and forming his/her professional identity (Yaffe-Yanai, 2000).

The choice of a teaching profession has been found to connect to previous life experiences that influenced the students, such as significant role models who influenced them, or significant experiences relating to the field, or processes of internalization and identification with teachers who had taught them in the past (Katzin \& Shkedi, 2011). 
The sense of a social mission as a social motivator on the one hand and the fulfillment of needs as a personal motivator, on the other hand, are the main factors in choosing the teaching profession. In the sense of mission one can see the attitude towards the pupil, the attitudes towards society in order to establish continuity of cultural values and meaning as well as the pupil's attitude towards self (Brenner, Zelkovich \& Talker, 2002). The principle motivation for choosing teaching stems from internal factors. Commitment of teachers who emphasize these intrinsic motivating factors is higher than those who relate to extrinsic motivating factors (Katzain \& Shkedi, 2011).

Research reveals that choosing teaching in special education almost totally stems from intrinsic motivating factors (Tangala \& Margaret, 2007). The attributes characteristic of the special education teacher as described in research literature are: great commitment, creativity, flexibility, steadfastness in face of the unexpected, patience, tolerance, sensitivity and empathy towards others and desire to give, readiness to see work as a challenge and goal, ability and readiness to invest physical, intellectual and emotional effort in hard and complex work (Aboudi-Dangur, 1992; Ronen, 1988).

Teachers in special education come to the profession with a conscious decision, formed over the years of their lives, to devote themselves to this emotionally demanding work, which requires daily assistance to weak and vulnerable members of society (Gavish \& Friedman, 2001).

\section{METHODOLOGY}

Narrative research based on life stories was chosen for this study from a wide range of alternative methods of interpretive research. Narrative research has achieved impressive results in recent years. No longer concerned with only past developments it also serves as a generative as well as expressive tool. Not only do narratives reflect identity, society, and culture, but the way they structure these factors establishes a connection between the researcher and the participant. The words used in narrative research are the basis for the data and the research focus moves from the universal, which can be classified and generalized, to the local and private, the personal and subjective (Clandinin, 2007; Freeman, 2007).

Numerous researchers posit that the human experience is a narrative experience, which can be best understood via stories. In the domain of education, the following researchers made significant contributions: Carter (1993); Clandinin and Connelly (1995, 1999); Craig (2001); Witherell and Noddings (1991) and others. A narrative is a story which an individual tells about the events of his life and it includes the perceptions, beliefs, and feelings via which his identity is revealed. A narrative is a live snapshot of the teller's identity or personality (De Fina, Schifrin \& Bamberg, 2007).

\section{Data Collection}

Avigail wrote her life story as an autobiography at the end of her last year of her college studies. For the purpose of this study, I asked her permission to use this autobiography. In addition, use was made of the researcher's reflective diary

\section{Method of Analysis}

The narrative was analyzed using the "Listening Guide" method (Brown \& Gilligan 1992, Gilligan et al 2003), which consists of a series of consequential listenings, each designed to promote the researcher's relationship with a person's unique voice by listening and referring 
to the different aspects of expression of his or her experience in a specific context. Each step in the Listening Guide requires the researcher's active presence and a desire to experience the unique subjectivity of each of the research participants. The researcher's voice is also an explicit part of the process.

Step 1: Listening for the plot consists of two parts: listening for the plot and the listener's response to the interview.

First, reading the text and listening for the plot by paying attention to what is going on or what stories are being told. Attention is also given to the background, or the multiple contexts within which the stories are embedded, as in narrative research the researcher can never be a "neutral" or "objective" observer. We focus on and actively and consciously record our responses. Following basic principles of reflexivity, we note our social location in relation to the participant, the nature of our relationship with him or her and our emotional responses.

Step 2: I poems - This listening focuses on the voice of the "I" who is speaking by use of this first-person pronoun and constructing "I poems". This step has a dual goal: first it is intended to press the researcher to listen to the participant's first-person voice, to absorb its rhythm and unique changes, and second, to hear how this person speaks about himself/herself. This step is a crucial component of the method as it allows for tuning in to another person's voice, and listening to what that person knows about himself or herself before talking about him or her. This is a way of starting a relationship that works against distancing ourselves from that person in an objectifying manner.

Construction of the "I poem" is governed by two guidelines: (1) underlining or selecting each first-person "I" within the chosen paragraph along with the verb and any seemingly important accompanying words; (2) maintaining the sequence in which these phrases appear in the text.

Then the underlined "I" phrases are extracted while keeping them in the order of their appearance in the text and placing each such phrase on a separate line, like the lines in a poem. The "I" poem captures an associative stream of consciousness conveyed by the first- person voice running through a narrative rather than being contained by the structure of full sentences. Cutting the text and focusing just on the "I" pronoun provides the aspect of subjectivity.

Step 3: Listening for Contrapuntal Voices brings the analysis back into relationship with the research question. It offers a way of hearing and developing an understanding of several different levels of a person's specific experience as it influences the questions which have been asked. This process entails reading the interview two or more times, so that each time we tune into one aspect of the story, or one of the voices used to express the person's experience.

Step 4: Composing an Analysis - after reading the text at least four times, in the final step, we can pull together everything we have learned about the person with regard to the research question. An interpretation of the interview or text is developed and synthesizes what has been learned through this entire process and an essay or analysis is composed. If we return to the research question, we can consider several questions such as, "What have you learned about this question through this process and how have you come to know this?" "What is the evidence on which you based your interpretations?"

\section{Ethics}

The contents are published after a number of years during which the participant works in the field as a teacher with a license from the Ministry of Education. The participant's name has been changed to protect her anonymity. 


\section{FINDINGS}

Avigail's story begins in childhood with background about her brother and the discovery of her disease.

I was born in southern Tel Aviv and at the age of 10 months, I moved with my parents to a Kibbutz. When I was a year and a half old, my brother was born. My brother was diagnosed with a rare problem with his vision when he was about 3 years old. Shortly afterwards, they also checked me and discovered that I also suffered from the same condition. Today I am considered visually impaired. My brother became totally blind at the age of 22 .

We both attended the regular Kibbutz school and graduated after 12 years of study with a full matriculation certificate. Following high school, I volunteered to do my 2 year National Service in a day clinic for people with slight mental deficiencies and cerebral palsy. Afterwards, I worked at various jobs and learned medical massage with the intention of working with people with special needs. The desire to help and be involved in work with populations outside the norm and my love for this population, led me to my studies towards a degree in special education.

My visual disability appeared when I was approximately 5 years old, following its discovery in my younger (18 months younger) brother's eyesight. My parents would take him for checkups at the hospital at least once a week. They recount that every time they were about to take him, I would say, "It's not fair, why are you only taking him? I want to go too!" And it was not long after the doctors decided that since the disease is rather rare in medical literature, the entire immediate family should be examined. Since then, we would spend time at the hospital at least once a week. The medical staff was comprised of a young beautiful gentle female professor, a few nurses and a doctor (who photographed the eye following the injection of fluid that colored eye cells). The hospital staff always received us with a smile.

I remember that each time after the examination, my parents would buy us a surprise.

After the first examination, the doctors determined the cause of the problem to be a genetic disease called Choroidal Osteoma, which damages the retina.

Since this disease is considered to be very rare, the doctors did not know exactly what to do, and therefore most of the time, they just examined us. Once, they decided to give us a laser treatment. The laser treatment did not help, but quite the opposite. It caused deterioration in my brother's eyesight, and in one of my eyes. Luckily for me, my father refused to continue the treatment as it was not helping at all. My parents then understood that there was no way to treat our degenerative disease and made the decision to leave it alone. We would go in for our not too frequent routine checkups and whenever we sensed any deterioration in our vision, we would initiate a visit to the doctor despite the fact we were aware there was nothing they could do about it.

My vision remained for the most part stable and sometimes at far infrequent intervals, it would deteriorate. My left eye hardly functions at all, it has only a narrow line of vision and even that is blurred and not continuous. My right eye has a relatively larger field of vision; however, the range of vision is to a distance of 1 meter and only when the lighting is strong enough, and the objects large enough. My vision is called 
"peripheral vision", in which the center of the picture is blurred and the sides are sharp and clear. This situation limits me in my everyday life, mainly when I find myself in new places, on public transportation, and in the myriad of small matters of daily life, which are too numerous to list. My vision can be reduced to total blindness, as happened in the case of my brother. Yes, I am scared to death.

Though some of the solutions seem clear to me today, blindness remains unknown to me - darkness. Insofar as my other senses fill a significant place of pleasure in my life, yet the point of light I have is most significant for me. However, I try not to think about it and when these thoughts do cross my mind, I dwell on this a bit, try to give myself encouragement and then quickly cast away the thoughts from my mind.

The first "I" poem in which Avigail gives voice to her disability:

My visual disability appeared when I was approximately 5 years old

Treatment caused deterioration in my eyesight,

My field of vision is narrow

My left eye hardly functions at all

My vision can be reduced to total blindness

I am scared to death.

Blindness remains unknown to me - darkness

Avigail's tremendous fears concerning total blindness can be seen in this poem. She speaks of dying of fear. She then speaks about her parents' choice to make her cope and be independent at all costs:

I don't know how my parents felt when they found out both their children were afflicted with this visual disability. I also don't know how my parents felt about the fact this disease is very rare and is the outcome of their genetic combination. What I do know is they always related to us children as being capable of whatever we wanted.

I remember when I was about 9 years old, my father was determined that I take an active part in the household chores. Washing dishes was the first chore he insisted I master. In response I said, "But I always drop and break everything" Father answered, "As far as I am concerned, everything can break! Worst scenario, I'll have to replace everything" Finally, despite many broken dishes, I did learn how to wash dishes and help my mother in the house. This memory illustrates the determination with which my parents gave me independence.

Avigail feels that her parents' insisting on raising her to be an independent person is the greatest gift they could give her.

My parents let society know that we were children just like all children and they were not ashamed of our disability. These messages enabled us to feel we were an integral part of the Kibbutz. It wasn't that they ignored the disease or disability, but rather they related to it in the technical, physical sense, that is to say, they found technical solutions for whatever they could, without drawing undue attention to us.

Also my grandmother, may she be blessed with a continued healthy life, showed us that where there is a will there is a way! 
My grandmother did all her housework by herself. She raised five daughters in her home of one and a half rooms, did the laundry, cooked, baked and all with her own ten fingers and two keen ears. She knew everything through her sharp sense of hearing. We were always amazed how she did it. Her message was - live! She never despaired or gave up because of her limitation.

This was the atmosphere in which we grew up and which formed my personality. Thus I never felt different, an outsider or unusual on account of my disability. People who surrounded me in my childhood let me feel fully part of everyone.

As Avigail spoke, I thought about my own grandmother who became blind as a result of her glaucoma. My grandmother, just like Avigail's grandmother, never considered herself to be disabled, and showed she could do everything even without seeing. The influence of the environment on Avigail's blind grandmother and her own self-image, due to the way was brought up, ensure that she did not feel different.

An additional obstacle I had to overcome as a result of my external disability was my fear of new places and sleeping in strange places. Therefore I was never eager to sleepover at my friends' houses or join them on trips or hikes with our youth movement, "HaShomer HaTzair". Another thing that created a sense of being different, loneliness and my feeling of not belonging, in contrast to my friends, was our twelfth grade school field trip.

We were supposed to go on our annual school trip, the most significant in a teenager's life in Israel - the last trip and most worthwhile, the trip to Eilat. But I was more scared and anxious than excited and therefore I decided not to go on the trip. To the credit of my homeroom teacher, who in spite of my protests, shouts, and obstinacy, did not give up on me "You are part of this class and you will participate with everyone else in the class." This sentence is etched in my memory and in every step I take. He showed me that I belonged.

This is the greatest gift a person can receive. Naturally, he was not oblivious to my disability or my hesitation, and promised to find a solution for each one of my fears. I did finally go on the school trip and I enjoyed it thoroughly. I have many memories from that trip, and would not give up any of them. On a mountain hike, I had a security guard who stayed by my side, every teenage girl's dream come true, and at night, I was accompanied by girls who were aware and accepting of my fears. During that week I discovered the extent to which my classmates were aware of and accepting of me and how much they valued me. In our yearbook, near my picture they added the quotation "She was stronger than the winter storm" from Gali Atari's song "Stronger than the Wind"

This statement, black on white, echoes in my head every time I feel I'm at a breaking point. I tell myself - if people see me as being strong, then I must be that way. They helped me discover my inner strengths.

Acceptance by the environment towards a person with special needs, the high school teacher who knew how to offer a sense of belonging without giving in and friends who were helpful to Avigail and enabled her to see her worth and strength. 
Lack of knowledge and society's basic ignorance about people with special needs in general and specific types of disability in particular, often place the other and the "normal" person in situations that are challenging, difficult and painful for both sides.

As far as I am concerned, to look a stranger straight in the eye, to turn to a total stranger in the street who does not know me, is an unpleasant and uncomfortable situation because when I look someone in the eye, I do so by turning the pupils in my eyes upwards. Simple routine actions like taking a bus or any public transportation, crossing streets, shopping, etc, things that a seeing person does without giving it a second thought, is for me a task accompanied by anxiety, and constant tension, a never ending embarrassing struggle.

One of the things that helps me to remain strong and continue are my friends, whom I meet with or talk to after my daily battles. The fact that they treat me as an equal, don't relate to me with pity, but rather in the same way they relate to each other, saves my sanity. This feeling of normalcy and belonging that I get from my friends, is my main ammunition in combating the eternal war of my life.

In the hardships of daily situations as well, Avigail is sustained by her friends who maintain her sense of belonging and normalcy. Avigail began her studies in another college for special education where she was required to study regular education. This did not meet her expectations, aspiration or abilities.

The first and last time, I hope, in which I gave up and quit was at the end of the third semester of studies in special education. I remember having no deliberations or doubts about what I wanted to study but only on how I would do that. My impairment bothered me and made me paralyzed by fear

During my first week of studies, I felt overwhelmed, I felt "out of it", lost and very "abnormal". I would finish a day of classes in tears, after having sat in a class for an hour and a half with tears streaming down my face, wondering "What am I doing here?" When I got home, I decided to quit my studies and find a job in the field of special education, without having a degree.

Two days later, I received a phone call from the Head of the Special Education Department After a short conversation, in which I shared my fears, difficulties and feelings, she asked me to give it one more chance for a month and to make a decision then. That week I did not resume my studies. I felt the need to gather strength anew, to believe in myself once again. And indeed, I did return to classes the following week.

The next three semesters were for me enjoyable but difficult. I met new friends who gave me strength day to day, boosted my self-confidence and helped me forge a more mature professional identity. Towards the end of the third semester, I was informed that it was mandatory for each student to teach in both mainstream and special education in order to graduate with a teaching degree. I looked at the Head of the Department and reminded her that was my first question when I came to register at the college. I also reminded her that she had promised me all the adjustments I might need. She replied that the Ministry of Education would not accredit a teaching degree unless the student did an internship in the mainstream educational system. I looked at her and stated seriously and with pain, "I cannot teach a class of 40 students in a mainstream class, when I can barely see the pupils sitting in the first row. I don't need 
that certificate. I will never teach in a mainstream school." She replied, "That's the way it is." I left the room and decided I had no urge to continue fighting. No strength left! I decided to quit. The last day of the semester I came to pedagogy class, quieter than usual, I decided to tell the class of my decision and share my deliberations until my voice cracked and a flood of tears poured out of my eyes down my cheeks. I will never forget that day. It was so painful but nonetheless, I discovered how important I was to my friends, and how concerned they were about my welfare and how much they valued me. They all surrounded me with questions and embraces, as they protested and tried to convince me not to quit. But I had already given up. My walls crumbled and my heart shattered into pieces.

In the following poem, the voice of limitation and the shattering of a dream is expressed.

I gave up and quit

My vision impairment made me paralyzed by fear

I felt "out of it", lost and very "abnormal".

I would finish a day of classes in tears

"What am I doing here?" I decided to quit my studies

I had no urge to continue fighting. No strength left!

My voice cracked and a flood of tears poured out of my eyes down my cheeks.

My walls crumbled and my heart shattered into pieces.

The poem reveals Avigail's disappointment about broken promises and her inability to continue towards the realization of her dream.

A few months later after trying to heal the wounds, I decided I would reach a place "that would make me feel good", working with a special population, in a different way, through touch. I decided to learn medical massage at the Wingate Institute. I worked in an institution for people with slight mental deficiencies and cerebral palsy for a year. I combined these two fields and had no intention whatsoever to return to my studies for a degree. Nor did I consider attending a different academic institution. The thought of continuing my academic studies reminded me of my pain; the pain of feeling disappointed in myself for failing to fight for my rights.

This was the situation on the day I happened to meet, either purely by accident or by fate, a woman who introduced herself as the Head of the Special Education Department in an academic institution, other than the one I had attended. She presented herself after I had led a tour called "Dialogue in Darkness. "1 I remember this moment as if it happened yesterday. She claimed that she could see that I would be an excellent teacher and insisted that I study in her department. I resisted, of course, and told her I had already been burnt once and did not plan to repeat the experience. When she left, I slowly felt in every passing thought how I felt more alive. I felt as if I had been shut down till that moment. The thought of my being able to officially teach in special education, while expanding my knowledge in that area, filled me with life and pushed aside all the fears that had paralyzed me and the pain of my previous experience. A month later, I found myself in her office for an interview to be accepted 
to her department, at the end of which I understood I was about to complete my studies for a BA in Special Education, in another two months.

Today, when I have almost completed my studies, I am grateful for the opportunity that was given to me to prove to society that I am capable. And it is important to prove to myself, to remind myself that I have only to desire and to believe in myself since apparently I do have the strength.

This is how I met Avigail, in total darkness, during a guided tour with second year students at a program called "Dialogue in Darkness" While walking in total darkness, I carried on a conversation with her, and she told me how she had left her studies at a different college because of their requirement that she teach in a mainstream classroom. I heard the confidence in her voice and I understood that she could be an outstanding teacher. I tried to convince her to return to her studies in my department and so it was.

The following "I" poem emphasizes the voice of capability. Sometimes enabling is all that it takes:

I slowly felt in every passing thought how I felt more alive.

The thought of my being able to officially teach in special education

filled me with life and pushed aside all the fears that had paralyzed me and the pain of

my previous experience,

I understood I was about to complete my studies for a BA in special education

I am grateful for the opportunity that was given to me to prove to society that I am capable.

And it is important to prove to myself, to remind myself

I have only to desire and to believe in myself since apparently I do have the strength.

In this poem Avigail is encouraged only by the thought of this opportunity to return to her studies, to fulfill her dream, to prove to society and to herself that she has the strength. Avigail concluded her studies successfully and became a teacher, beloved by her pupils.

Sometimes action and giving to others if part of self-therapy:

"Weren't you disgusted?" "Hats off to you - this is really holy work" - These were the words I heard all the time from the moment I began my National Service in a day clinic for people with slight mental deficiencies and cerebral palsy. The truth is my sentiments were the same for the first week I worked there. But from the second week and onwards I could only see the strength and satisfaction I derived from this special population. Every day I spent with them forced me to look at my life and to thank God for my life and smile!

After my national service, I worked at a similar place once a week. I would eagerly await the day I was to work there - it was like food for my soul. Their smiles, the small changes that took place after much work and the way they perceive you. Adults with special needs see the whole person, who he or she truly is. Today as I stand at the threshold of my professional life as an educator, I draw strength from my students. Their reactions and approach give me more than double what I give them. The feeling that somebody needs you and you can help is a most gratifying feeling, how much more so for a person like me whom society usually perceives as limited or disabled! The very act of doing for others and the ability to help them, even a bit, is the source of a sense feeling of inner happiness. 
The following "I" poem is also about capability:

I could only see the strength and satisfaction I derived from this special population.

Look at my life and to thank God for my life and smile!

Food for my soul. Their smiles,

I draw strength from my students.

The feeling that somebody needs you and you can help is a most gratifying feeling

Abigail reiterates the satisfaction that she got from her students' success and how their smiles fill her with strength.

\section{DISCUSSION}

Throughout life, each person is exposed to inclusion of different sorts: inclusion that the person himself experiences with a friend, student, teacher, or a family member. Inclusion occurs as a result of this passing encounter with a challenge or difficulty. Inclusion is two directional. On the one side, there is the person who includes, accompanies, assists, and copes with difficulty of the other. On the other side, there is the person being included, who believes in us, in the hope we inspire by our company and effort we invest in him or her. The experience is generally empowering and powerful for both sides.

In this study, we have seen the participant who, on the one hand, is in need of inclusion, sometimes included and sometimes not, and on the other hand, his/her ability to provide inclusion. Actually her only request was "Include me as a visually disabled person in academia, so that I may in turn include children with special needs in my role as a teacher."

Avigail grew up with a visual disability. In the process of her narrative, she notes the disability and the difficulties involved in managing in her surroundings, but she also emphasizes the inclusion on the part of her immediate surroundings, her parents, friends and high school teacher, all of whom gave her the strength to become independent and succeed.

At the same time, Avigail describes her life dream of working with people with special needs, to include others. This dream had developed at an early age, and was realized in her voluntary national service, where she worked for two years in a day clinic for people with slight mental deficiencies and cerebral palsy. Afterwards she worked in various jobs with people with special needs. Her desire to help others and be involved in working with this population led her to special education studies.

In the last decade, the motivation of those turning to teaching in special education has been the subject of much research. As found in this research the desire to work in special education is connected with some positive experience with a different other, either personally or in the family (Hillel-Lavian, 2003, 2009; Tangala \& Margaret, 2007). The human wish to do work that has personal meaning is an existential need. A strong sense of self-identity is a necessary condition for achieving self-actualization in a career (Court, Merav, \& Ornan, 2009). A person chooses a profession or career with the aim of fulfilling his or her self-image and forming his or her professional identity (Yaffe-Yanai, 2000). Avigail's life as a visually impaired person, in addition to her personality and attributes, led her to her to wish to be at a place where she could include others. 
She then decided to study special education, she was accepted and from the start, discussed her limitation openly, among them her inability to teach a mainstream class. Avigail almost broke down at the beginning of her studies because of the demands of the academic workload and the accompanying emotional difficulties. One of the major difficulties accompanying disability is problems in social functioning, which stems from, inter alia, behavioral problems and low self image (Dahan \& Ziv, 2012). The problem lies not only in overcoming the hurdle of being accepted into an academic setting, but rather continues after enrollment. These students continue to face challenges that are far from being simple. They students cope with tension and anxiety, in comparison with students who do not have disabilities.

Specifically, students report a high level of anxiety, low self-image and a wide gap between their capabilities and academic achievements (Barton \& Fushrman, 1994). They experience frustration while studying, and are hindered by organizational problems which make the learning process more difficult (Harrison, Areepattamannil \& Freeman, 2012). These emotional problems are accompanied by difficulties in the area of learning, with which they must cope. Luckily for Avigail, her department head included her and encouraged her to continue her studies; however, at the end of her second year, she again experienced lack of inclusion when she realized she was expected to do her student teaching in front of a mainstream class. Her reservations were not respected and she quit her studies with a feeling of disappointment and of having missed an opportunity.

Meanwhile Avigail worked in the Children's Museum in Holon in an exhibition called "Dialogue in Darkness", where tours are given to the public in total darkness so that theycould experience the disability. There I met her and invited her to continue towards her diploma and teacher's degree at Levinsky college.

In research conducted by Mander \&Naon (2002), the interviewees stated that a significant component in their success in coping with the world at large was the support and help they received from various people throughout their lives; people who opened windows of opportunity for them. And indeed, sometimes, no more is needed than a small window of opportunity. Avigail continued her studies and completed them with success and immediately got a job in a school for children with emotional problems. The window of opportunity at the beginning - her acceptance into academic studies, her inclusion further on, Avigail became a large container.

Society's lack of knowledge and basic understanding of people with special needs in general and of various types of disability in particular, often place the person and the "normal" other in challenging and trying situations, painful to both sides. A glass wall has been erected, fed to a certain degree by stereotype of disability as a disease (Reiter, 2004).

As academics, we are obligated to break the glass ceiling and allow each person selfactualization in higher education by adjusting the criteria for acceptance into institutions of higher education, and after enrollment, by ensuring each person's inclusion through accessibility, compatibility and primarily, by listening to his or her voice. 


\section{References}

Aboudi-Dangour, A. (1992). Correlation between Burnout and Idealistic Commitment, Social support and Self-Cfficacy among Special Education Teachers. MA thesis. Tel Aviv university (In Hebrew).

Barton, R. S., \& Fuhrman, B. S. (1994). Counseling and psychotherapy for adults with learning disabilities. In P. J. Gerber \& H. B. Reiff (Eds.), Learning Disabilities in Adulthood: Persisting Problems and Evolving Issues (pp. 82-92). Austin, TX: PROED.

Brown, L. M., \& Gilligan, C. (1992). Meeting at the crossroads. New York: Ballantine Books

Brenner, R. Zelikovich, S. and Talker, A. (2002). Development of the teacher's role perception among student-teachers in their first year, as expressed via reflective tools. Hachinuch Usvivato, $243-24$ (In Hebrew)

Carter, K. (1993). The place of story in the study of teaching and teacher education Educational Researcher, $22,5-12$.

Clandinin, D. J., \& Connelly, F. M. (1995).Teachers professional knowledge landscapes New York, NY: Teachers College Press.

Clandinin, D. J. (Ed.). (2007). Handbook of narrative inquiry: Mapping a methodology. California: Sage Publications.

Connelly, F. M., \& Clandinin, D. J. (Eds.) (1999). Shaping a professional identity: Stories of educational practice. New York: Teachers College Press.

Craig, C. J. (2001). No satisfaction: A case of the monkey's paw, top-down school reform, and the conduit.Curriculum Inquiry, 31,3.

Court, D., Merav, L.\& Ornan, E. (2009). Preschool teachers' narratives: a window on personal-professional history, values and beliefs. International Journal of Early Years Education.17 (3), 207 -217.

Dahan, A. Ziv, A. (2012). Adjusting Testing to Students with Learning Disabilities (Adapted to adult vocational training programs). Jerusalem: Ministry of Industry, Trade and Employment, Department of Training and Development - Personnel, Pedagogy Field (In Hebrew)

De Fina, A., Schifrin, D., \& Bamberg, M. (2007).Discourse and identity. Cambridge: Cambridge University Press.

Elbaz-Luwisch, P. (2002). Teachers' Narratives: The personal, the professional that which is between them. In: Zellermayer, M., Perry, P. (Eds). Teachers in Israel: a Feminist Outlook (113 - 115). Tel Aviv: Hakibbutz Ha'Meuchad (In Hebrew).

Forrest, M., Keener, T. \& Harkins, M. J. (2010). Understanding narrative relations in teacher education .AsiaPacific Journal of Teacher Education. 38 (2,) 87 -101.

Freeman, M. (2007). Autobiographical understanding and narrative inquiry. In J. Clandinin (Ed.), Handbook of narrative inquiry: Mapping a methodology (pp. 120-145). California: Sage Publications.

Friedman, I. (2011). Teachers' role expectations. Megamot, Vol 28 (1) 3-36. (In Hebrew)

Gavish, B. \& Friedman, I. (2001). Gaps in perception of the teacher's job and their correlation to the pressures of teaching. Readings in Educational Management and Organization Vol. 24. Haifa: Faculty of Education, University of Haifa, and Israel Teachers Union (Hebrew). 
Gilligan C, Spencer R., Weinberg, M.K. \& Bertsch T.(2003) "On the Listening Guide: A voice-centered relational method." In Camic, P.M., Rhodes, J.E. \& Yardley, L. (Eds.) Qualitative research in psychology: Expanding perspectives in methodology and design. Washington, D.C: American Psychological Association Press

Harrison, A. G., Areepattamannil, S., \& Freeman, J. (2012). Effects of the Learning Opportunities Task Force (LOTF) Programs on Postsecondary Students with Learning Disabilities. Exceptionality Education International, 22(1), 55-69

Hillel Lavian, R. (2003). Perceptions of Role Complexity, Stress and School Organizational Climate and their Impact on Burnout and Leaving the Profession among Special Education Teachers in Regular Schools. Thesis in partial requirement for degree of Doctor of Philosophy, Ben-Gurion University, Beer Sheba, Israel (Hebrew).

Hillel Lavian R. (2008). Motives for Choosing Teaching Special Education Research Report submitted to the Committee of Research Encouragement. Tel Aviv: Levinsky College of Education (In Hebrew)

Hillel Lavian R. (2009). You and I will Change the World - Student-Teachers' Motives in Choosing Special Education. Issues in Special Education and Rehabilitation , 24 (2) pp. 49 - 66. Haifa: Achva Publications, Haifa University (In Hebrew)

Katzin, A. Shkedi, A. (2011). Factors affecting enrollment in the program for training outstanding students for teaching. Case Study. Dapim, 51. Tel Aviv: Mofet Institute (In Hebrew)

Mandler, D. \& Naon, D. (2003). Evaluation of a Supported Employment Program Implemented by Jerusalem ELWYN for People with Mental Retardation. Jerusalem: Joint: Brook dale Institute (In Hebrew)

Mellard, D. F., \& Hazel, J. S. (1992). Social competencies as a pathway life transitions. Learning Disability Quarterly, 15, 251-271

Reiter, S. (2004). Circles of Brotherhood for Breaking the Link between disability and Loneliness. Haifa: Achva Publications (In Hebrew)

Ronen, H. (1988). Normalization as an ideal: On integrating the disabled into society. Hed Hachinuch, 60(4), pp. 11-12 (In Hebrew).

Tangala M. D.; Nauta, Margaret M. (2007) Values, Motivations, and Learning Experiences of Future Professionals: Who Wants to Serve Underserved Populations? Professional Psychology: Research and Practice, Vol 36(6), Dec 2005, 688-694.

Witherell, C., \& Noddings, N. (1991).Stories lives tell: Narrative and dialogue in education. New York, NY: Teachers College Press.

Yafe-Yanai, A. (2000). Every individual has a path - On accomplishment, love, career and mission. Tel Aviv: Modan Publishers (Hebrew).

The Author: Dr. Rivka Hillel Lavian, Senior Lecturer. Served as the Head of the Special Education Department. Currently the head of the Graduate School. Levinsky College of Education, Tel Aviv, Israel 